\title{
TECHNOLOGY AND ENERGY BALANCE IN STUMP HARVESTING WITH MCR500
}

\author{
Agris Zimelis ${ }^{1}$, Linards Sisenis ${ }^{2}$, Ziedonis Sarmulis², Sergey Ariko ${ }^{3}$ \\ ${ }^{1}$ Latvian State Forest Research Institute "Silava", Latvia; \\ ${ }^{2}$ Latvia University of Life Sciences and Technologies, Latvia; \\ ${ }^{3}$ Belarusian State Technological University, Belarus \\ agris.zimelis@silava.lv
}

\begin{abstract}
With the increasing demand for renewable energy in the domestic market, additional attention is paid to the use of stump-wood in energy supply. The stump harvesting technology is not substantiated sufficiently so that the end users can use this unpredictable raw material to generate heat and power. Service providing logging companies need to know the specific requirements to equipment and the characteristics of stump harvesting technologies in order to assess the possibility of acquiring this natural resource. The stump harvesting should be planned along with the regenerative felling, because the layout of the timber forwarding roads and the characteristic of the logging residues layer on the road surface are important. In its turn, when planning the upper timber yard, it is necessary to take into account the meteorological data, the prevailing wind direction and water streams. The aim of the study is to find out the total energy balance during the stump extraction with the MCR500 bucket. Working time, output volumes and productivity indicators are derived from the project "Development and testing of a prototype of multifunctional equipment for stump-wood production and preparation of the soil mounds" (2DP/2.1.1.1.0/10/APIA/VIAA/174) results and from the results of the joint stock company "Latvia state forest" project implemented in 2008. The most energy-consuming process is comminution of biomass, therefore it is common, for instance, in Finland that electricity-operated equipment located near the customer is used to carry out this work. More efficient use of forest resources by stump extraction and further utilization in heat and power production can increase biomass deliveries for energy applications by 500 thousand tons of dry matter of currently unused coniferous stump biomass annually.
\end{abstract}

Keywords: stump extraction, MCR500, biofuel.

\section{Introduction}

The share of renewable energy in the global power grid has changed dramatically in the world by $13.1 \%$ in 2000, but after 14 years it reached $14.1 \%$ [1].

Stump-extraction is well-known from ancient times in Scandinavian countries. The first publications on this issue are found circa year 1831 [2]. During the 1980-ies there was an attempt to ensure even a paper making plant with stump-wood as raw material, but it had interrupted after ten years. In Latvia the first investigations on stump-lifting appeared during the second half of the $19^{\text {th }}$ century and continued during the last decade [3]. There is no stump-stump extraction practice in the forests in Latvia nowadays, unless in the cases of the road construction, or an establishment of new forest seed orchards with the exception of the land abandoned in 2018 in Jelgava, where issues of development methods and overall energy efficiency were raised.

Different stump-extraction mechanisms are described in the investigation, made by Kalle Kärhä in Finland. Two stump-lifting technological patterns, based on two different buckets, suitable to aggregate with the same excavator, were compared. The main difference between both cases was the diverse mode of the implementation of the necessary movements by a relevant bucket to get the stump out of the ground [4]. The description of the new technology for stump uprooting is available in the recent review (2015) of the newest technologies to obtain bioenergy from forest in Finland. The construction of buckets is developed by Karelian Puu Ja Metalli Oy. This stump-lifting technology can be described as follows: to clench the stump there are 4 wedge-shape elements at both ends of every 4 blades. After clenching the stump with wedge-shape elements, it is pulled out of the ground and split into 4 parts simultaneously. The stump lifting force is smaller due to the simultaneous motions of lifting and splitting, so this bucket is suitable for mounting and operating with forwarders [5]. Dimitris Athanassiadis emphasizes the advantages of the stump-lifting technology in Sweden, using the Pallari KH 160 bucket, which is mounted on the excavator and is applicable to lift and split the stump simultaneously during the extraction process. To get stump parts clear of soil particles and stones, shaking of each piece is needed after it has been lifted above the ground level. On the research basis of this technology the figures on the productive work time distribution show that $17 \%$ of the work time has been spent for lifting, $32 \%$ - to split stumps, and the same amount of time - to put the stumps into a stack [6]. Created in Latvia prototype of the stump-lifting bucket MCR500 encompasses 
both an apparatus for stump uprooting and a device for soil scarification before forest planting. This prototype is intended for fast mounting on a middle-class (12-15tonnes) tracked excavator. The stumplifting bucket consists of two stationary knives and an opposite knife to split the stump after lifting [7], [8].

Tree stumps, harvested after regenerative fellings, are a remarkable source of renewable energy resources that under optimum conditions can provide 150 to $200 \mathrm{MWh}$ of primary energy from each hectare. The research in Estonia, a neighbor country of Latvia, shows greater potential - up to $290 \mathrm{MWh} \cdot \mathrm{ha}^{-1}$ [9]. It is possible to combine both stump-lifting and soil scarification for forest planting. In addition, another positive effect of tree stump harvesting is a remarkable chance to minimize the further prevalence of root-rot, because considerable proportion of rotten wood is removed together with tree stumps. Stump-wood chips are applicable as fuel for heat and power plants [10].

Soil preparation for forest planting in combination with stump-lifting is applicable in case, if the stump lifting bucked is equipped with separate soil scarification plate, which is able to make mounds with sufficient scarified area. Stump splitting knifes can be used for soil scarification to enhance natural regeneration of pine stands. Both operations, stump extraction and soil scarification can be done simultaneously [8].

\section{Materials and methods}

Energy efficiency of stump extraction can be increased by reduction the amount of energy consumed in the production process without reducing the volume and quality of production. Energy efficient solutions enable the manufacturer to reduce the cost of the product. By analyzing the overall effect of the energy efficiency targeted improvement measures in the stump extraction process, the technology and the overall $\mathrm{CO}_{2}$ balance can be improved.

The energy balance concept covers the direct energy consumption, human energy and machine energy, which is consumed during the production process. In the study, energy efficiency is assessed on the basis of the energy input from the fuel consumption.

The calculation of energy efficiency in straw production is based on the formulas published by Loffler (2001), in which the amount of renewable energy produced is attributed to 10001 of diesel consumed. In turn, the energy efficiency of resources is calculated as the basis for calculating the efficiency factor (diesel fuel $9.88 \mathrm{kWh} \cdot 1^{-1}$, but the amount of energy from stump wood from one loose volume $\mathrm{m}^{3}-200 \mathrm{kWh}$ ).

Energy consumption per hour $\left(L_{u}\right)$ is converted into energy consumption per cubic meter, in terms of productivity, using the formula $[11](1,2,3)$.

$$
\begin{aligned}
& L_{u}=\frac{L_{h}}{P T}, \\
& P T=\frac{60}{T_{0}},
\end{aligned}
$$

where $\quad L_{h}$ - fuel consumption, $1 \cdot h^{-1}$;

$P T$ - labor productivity, $\mathrm{m}^{3} \cdot \mathrm{h}^{-1}$

$T_{0}$ - consumed time, $\min \cdot\left(\mathrm{m}^{3}\right)^{-1}$.

$$
L_{h}=\frac{L_{h p} \times P_{h p} \times F_{c}}{W},
$$

where $L_{h p}-$ fuel consumption rate per horsepower $\left(0.17 \mathrm{~kg} \cdot(\mathrm{hp} \cdot \mathrm{h})^{-1}\right)$;

$P_{h p}$ - engine power, hp;

$F_{c}$ - load factor, estimated to be 0.54 for tractors and 0.38 for trucks;

$W$ - fuel weight $\left(0.84 \mathrm{~kg} \cdot \mathrm{l}^{-1}\right)$.

In order to be able to compare the total power supply between different development options, it is necessary to calculate the energy efficiency coefficient $\eta_{e}$ and $\eta_{c}$ by formulas 4 and 5 [11]: 


$$
\begin{gathered}
\eta_{e}=\frac{1000}{\sum L_{u}}, \\
\eta_{c}=\frac{200}{\sum L_{u} \times 10} .
\end{gathered}
$$

Labor productivity indices in stump lifting, delivery, comminution and further transport are assumed according to the results of the projects of the stump lifting carried out by the Silava LVMI in 2007: "Extraction of energy resources and growing in the grooms from ditch overgrowth, strain processing, evaluating economic, technological and environmental factors" (2010) and "Multifunctional strain development and soil preparation equipment prototype creation and testing" (2016). Productivity rates for stump-lifting, forwarding and road transport, and after-harvesting processing are calculated after fieldwork timing, Table 1.

Table 1

\section{Work elements}

\begin{tabular}{|c|c|c|c|c|c|}
\hline No & Stump lifting & Forwarding & $\begin{array}{c}\text { Stump } \\
\text { transporting }\end{array}$ & Chipping & $\begin{array}{c}\text { Chip } \\
\text { transport }\end{array}$ \\
\hline 1. & Tower turns & $\begin{array}{c}\text { Driving in } \\
\text { stand }\end{array}$ & Preparing work & Preparing work & Preparing work \\
\hline 2. & $\begin{array}{c}\text { Driving in } \\
\text { stand }\end{array}$ & $\begin{array}{c}\text { Manipulations } \\
\text { with crane }\end{array}$ & $\begin{array}{c}\text { Manipulations } \\
\text { with crane }\end{array}$ & Chipping & Waiting \\
\hline 3. & Reaching & Catching & Catching & $\begin{array}{c}\text { Non-work } \\
\text { operations }\end{array}$ & Driving \\
\hline 4. & Catching & Loading & Loading & - & $\begin{array}{c}\text { Non-work } \\
\text { operations }\end{array}$ \\
\hline 5. & Pulling & Unloading & Unloading & - & - \\
\hline 6. & Splitting & Sorting & $\begin{array}{c}\text { Other } \\
\text { operations }\end{array}$ & - & - \\
\hline 7. & Shaking & $\begin{array}{c}\text { Other } \\
\text { operations }\end{array}$ & - & - & - \\
\hline 8. & Dropping & $\begin{array}{c}\text { Non-work } \\
\text { operations }\end{array}$ & - & - & - \\
\hline 9. & Other operation & Empty driving & - & - & - \\
\hline 10. & $\begin{array}{c}\text { Non-work } \\
\text { operations }\end{array}$ & - & - & - & - \\
\hline
\end{tabular}

The analysis of the stump extraction process includes logging, crushing and delivery of the material by road train (lorry with trailers). Two stump production scenarios are compared in the study, where the performance indicators are based on the past strain tracing research: (1) 2007 within the framework of the study machine-generated strain development including the farther away transport; (2) development of driven strains carried out within the scope of the 2010 study including road transport of chips. The calculation made in variants 1 and 2 foresees intermodal build-up.

Calculation of the net calorific value of stump biofuel is calculated from the results obtained in the study (formula 6) (LVS EN 14918:2010).

$$
q_{p, n e t, a r}=\left(\frac{q_{p, n e t, d a f} \times\left(100-A_{d}\right)}{100}\right) \times\left(\frac{100-M_{a r}}{100}\right)-0.02443 \times M_{a r},
$$

where $q_{p, \text { net, ar }}$ - lowest calorific value, $\mathrm{MJ} \cdot \mathrm{kg}^{-1}$;

$q_{p, \text { net,daf }}-$ lowest calorific value without ash, $\mathrm{MJ} \cdot \mathrm{kg}^{-1}$;

$A_{d}$ - ash content, \%;

$M_{a r}$ - relative humidity at the place of delivery for fuel, $\%$. 


\section{Results and discussion}

Table 2 shows the energy efficiency of wood chip production depending from the scenario. The first option is based on the 2007 findings on productivity and fuel consumption. The stump lifting was done with a Komatsu PC210LC excavator, equipped with a CBI stump extraction bucket for middle sized stumps, the productivity obtained during the study is 1.81 tons $\cdot \mathrm{h}^{-1}$. The stumps were transported to roadside with a John Deere 1110D forwarder; the productivity of the off-road transport during the study was 6.6 tons $\cdot \mathrm{h}^{-1}$. The stump transport from roadside to intermediate storage is carried out by a container truck Scania R480, the performance achieved in the study was 14.7 tons $\cdot \mathrm{h}^{-1}$. Stump comminution was carried out with a CBI 6800-P-12 crusher with average productivity of 54.6 tons $\cdot \mathrm{h}^{-1}$. The further transport of wood chips was done with a semitrailer Scania R480, the productivity achieved in the study was 49 tons $\cdot \mathrm{h}^{-1}$. If the stumps are extracted according to this scenario, then 122 $\mathrm{m}^{3}$ of wood chips are produced per 10001 of the spent diesel fuel.

The second scenario is based on the study results obtained in 2010. Productivity and fuel consumption figures obtained in the study were used in calculation. The stumps were extracted with a New Holland E21B excavator, fitted with a stump head MCR500, productivity gained in the study was 1.86 tons $\cdot \mathrm{h}^{-1}$. Extracted stumps were transported to roadside with a Ponsse Gazelle forwarder with extended frame, the study yielded 2.6 tons $\cdot \mathrm{h}^{-1}$. Assumptions on stump transport to intermediate storage, comminution and transportation to the end use site were taken from the 2007 study. According to this scenario $137 \mathrm{~m}^{3}$ of wood chips are produced and delivered per 10001 of consumed diesel fuel.

The second scenario represents more efficient stump extraction method, however, the difference is only $6 \%$. It would be useful to carry out additional study on the production of stump wood chips in a processing company, while using electricity powered crushers, as is the case in the Scandinavian countries. Using stationary electricity powered crushers, theoretically it is possible to improve the overall energy efficiency by $13 \%$.

According to the data obtained so far, $83 \%$ of the energy consumption takes place in forest (stump harvesting and forwarding, road transport of stumps), but stump comminution and further road transport consumes only $17 \%$ of energy. Respectively, according to the study results replacement of the diesel powered crusher to electricity powered equipment will result in considerably smaller savings.

Table 2

Energy efficiency of stump lifting and processing

\begin{tabular}{|c|c|c|c|c|c|c|c|}
\hline $\begin{array}{l}\text { Opt. } \\
\text { No. }\end{array}$ & Work operation & Equipment & $\boldsymbol{P}_{t}$ & $L_{h}$ & $L_{u}$ & $\eta_{e}$ & $\eta_{c}$ \\
\hline \multirow{5}{*}{1} & Stump lifting & Komatsu PC210LC (CBI) & 4.64 & 18.03 & 3.89 & \multirow{5}{*}{128.61} & \multirow{5}{*}{2.46} \\
\hline & Forwarding & JD 1110D & 9.57 & 12.00 & 1.25 & & \\
\hline & Stump road transport & Scania R480 & 21.00 & 27.00 & 1.29 & & \\
\hline & Comminution & CBI 6800-P-12 & 84.00 & 80.75 & 0.96 & & \\
\hline & $\begin{array}{l}\text { Transportation of } \\
\text { wood chips }\end{array}$ & Scania R480 & 70.00 & 27.00 & 0.39 & & \\
\hline \multirow{5}{*}{2} & Stump lifting & $\begin{array}{l}\text { New Holland E215B } \\
\text { (MCR-500) }\end{array}$ & 4.93 & 17.49 & 3.55 & \multirow{5}{*}{137.26} & \multirow{5}{*}{2.63} \\
\hline & Forwarding & Ponsse Gazelle & 10.87 & 12.00 & 1.10 & & \\
\hline & Stump road transport & Scania R480 & 21.00 & 27.00 & 1.29 & & \\
\hline & Comminution & CBI 6800-P-12 & 84.00 & 80.75 & 0.96 & & \\
\hline & $\begin{array}{l}\text { Transportation of } \\
\text { wood chips }\end{array}$ & Scania R480 & 70.00 & 27.00 & 0.39 & & \\
\hline
\end{tabular}

The most visible benefit from using stationary crushers is the ability to choose electricity powered equipment; however, the evaluated scenarios clearly demonstrate that the fuel consumption during comminution of biomass is a minor factor determining the energy efficiency. In order to increase overall energy efficiency of the stump biofuel production, it is necessary to improve the harvesting 
technology so to increase the overall productivity. Sensitivity analysis in Fig. 1 shows that the most significant impact on energy efficiency is created by productivity of stump extraction $(\mathrm{N}=1700)$.

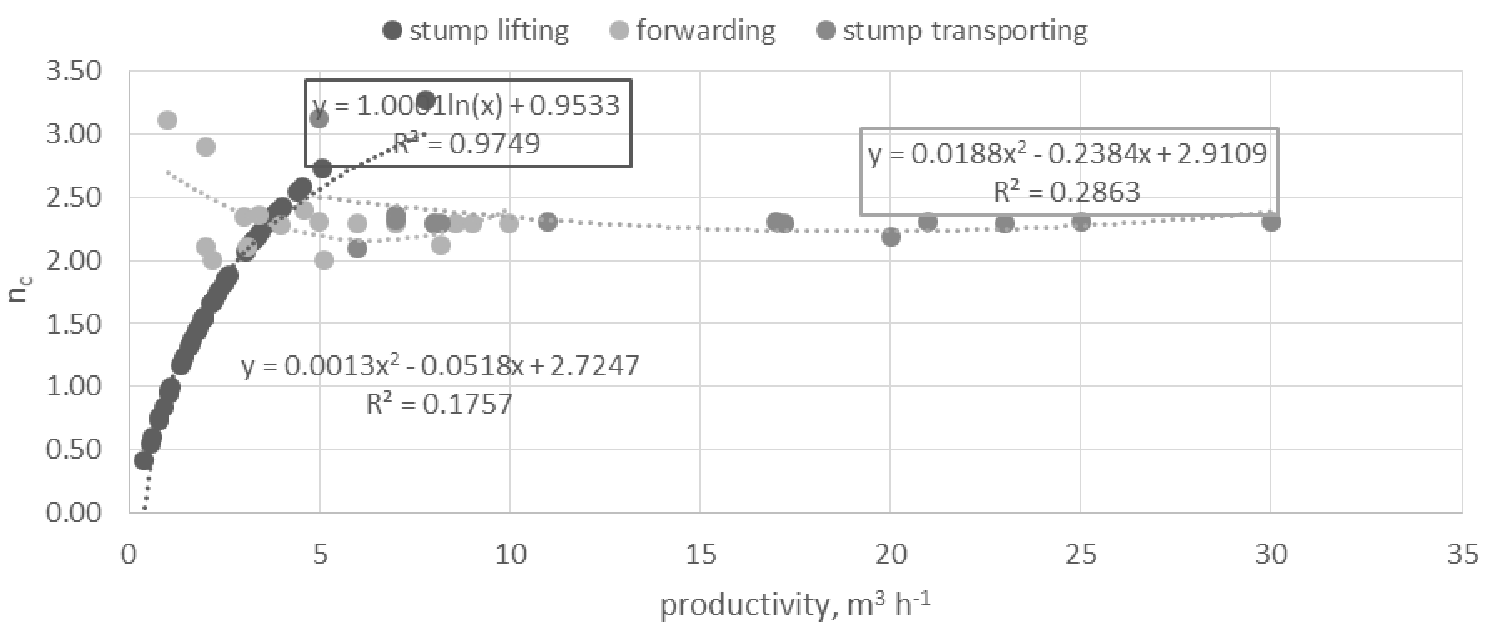

Fig. 1. Sensitivity analysis for stump lifting for forest operations

Productivity of comminution and wood chip transport (Fig. 2) has limited the impact on the energy efficiency. By achieving the productivity of 42 tons $\cdot \mathrm{h}^{-1}$ for the crusher and chip transport, the energy efficiency is around 2.7 .

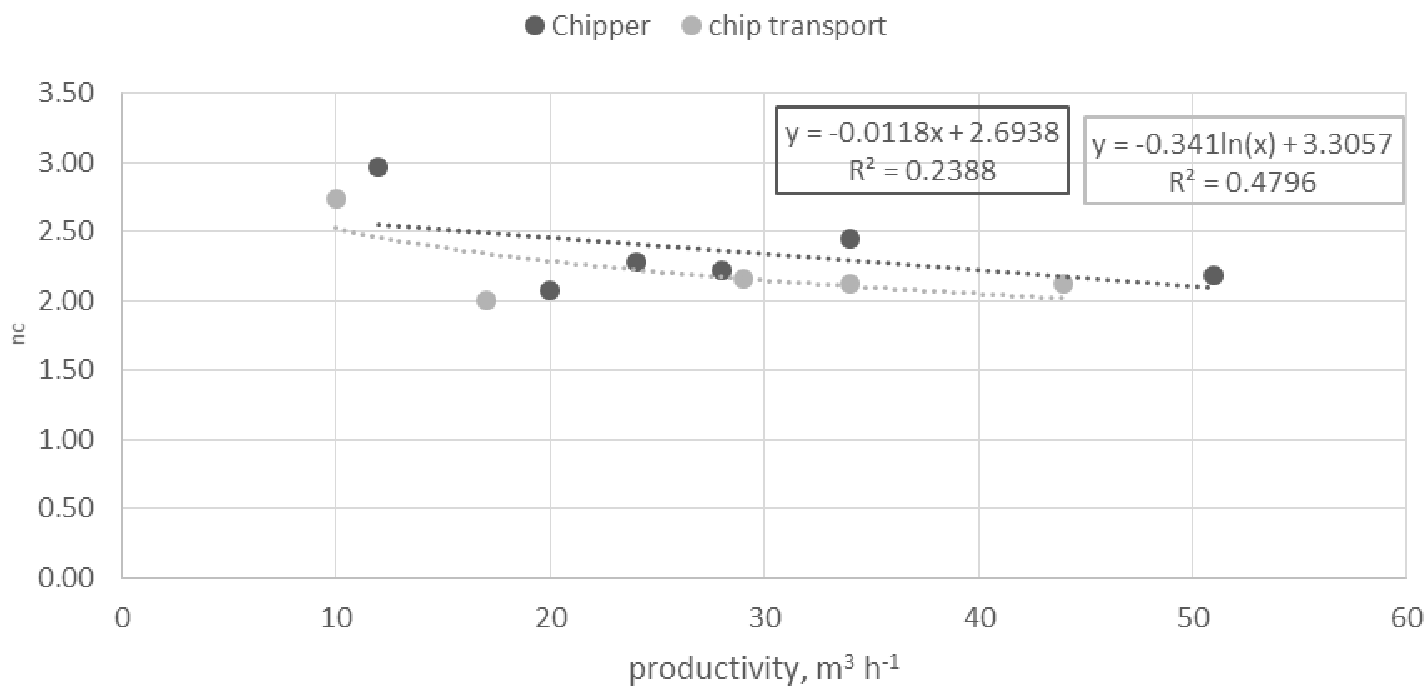

Fig. 2. Sensitivity analysis of energy efficiency of comminution and road transport of wood chips

\section{Conclusions}

1. The use of stump wood for heat and power production according to the results of earlier studies is more efficient, while using the MCR500 stump extraction bucket (scenario 2, $\eta_{c}=2.78$ ).

2. Productivity of stump extraction has the most significant impact on energy efficiency, therefore, the improvement of productivity is the primary solution to improve the energy efficiency.

3. Additional analysis on application of electricity powered crushers is needed to identify the potential of this technology in further improvement of energy efficiency.

\section{Acknowledgements}

The study is implemented within the scope of the memorandum between LSFRI Silava and Joint stock Company "Latvia state forests" from 11.10.2011. 


\section{References}

[1] Kummamuru B. "WBA GLOBAL BIOENERGY STATISTICS 2017," Stocholm, 2017.

[2] Persson T. "Stump harvesting for bioenergy - methods and environmental effects," Scand. J. For. Res., vol. 32, no. 3, 2017, pp. 201-203.

[3] Lazdinš A., Zimelis A., Lazdāns V. "Enerḡētiskās koksnes sagatavošanas tehnologijijas kopšanas cirtēs, galvenās izmantošanas cirtēs un meža infrastruktūras objektos," Salaspils, 2012.

[4] Kärhä K. "Comparison of Two Stump-Lifting Heads in Final Felling Norway Spruce Stand," Silva Fenn., vol. 46, no. 4, 2012.

[5] Metsätalous O. "Energiapuun varastointi, energiapuun varastointiohe (Energy wood storage, storage gude for energy wood)," 2012.

[6] Athanassiadis D., Lindroos O., Nordfjell T. "Pine and spruce stump harvesting productivity and costs using a Pallari KH 160 stump-lifting tool," Scand. J. For. Res., vol. 26, no. 5, 2011, pp. 437-445.

[7] Lazdins A., Zimelis A., Gusarevs I. "Preliminary data on the productivity of stump lifting head MCR-500," 2012.

[8] Lazdins A., Zimelis A. Latvian State Forest Research Inst. Silava, "Productivity of stump lifting head MCR-500," Mežzinātne, vol. 25(58), 2012, pp. $42-44$.

[9] Uri V. et al., "Biomass resource and environmental effects of Norway spruce (Picea abies) stump harvesting: An Estonian case study," 2015.

[10] Lazdiņa D. "Celmu izstrādes tehnologijas enerǵētiskās koksnes ražošanai," Salaspils, 2008.

[11] Loffler "Commercial timber harvesting in the natural forests of Mozambique," Rome, 2001. 